\title{
IS THERE A UNIVERSAL PATTERN FOR RECONCILIATIONS? SUCCESSES AND FAILURES OF EUROPEAN AND ASIAN RECONCILIATION AS A TOOL FOR THE BALKANS?
}

https://doi.org/10.18485/iipe_balkans_rssc.2020.ch9

Abstract: The postwar period brought not only the division of the world into two hostile camps but also the need to reconcile and work through the past wrongdoings. The world was amazed by Willy Brandt's knee-fall in Warsaw in 1970, and some of the countries took that as an example of the perfect reconciliation. Nonetheless, Polish-German apologies were not the ones that washed away all blame. The war memories still raise many emotions among the two nations. However, Japan and Korea, two allied democracies that still struggle with the war memories, frequently point to the European neighbors as a perfect example of reconciliation. The aim of this paper is to verify the strengths and weaknesses of European and Asian reconciliation and to find among them the working patterns for the Balkans, as well as the failures that should not be repeated.

Keywords: reconciliation, the Balkans, Europe, East Asia, politics of remembrance.

\section{INTRODUCTION - RECONCILIATION AND THE POLITICS OF REMEMBRANCE}

Fascination with other countries which are far away from each other is widely known all over the world. Due to its soft power ${ }^{2}$, Japan seems to be one of the most attractive countries. Korea is nowadays also gaining the attention of Europeans. European youth stay under the influence of Japanese

\footnotetext{
${ }^{1}$ Assistant Professor in the Institute of Middle and Far East Studies, Faculty of International and Political Studies, Jagiellonian University in Krakow, Poland.

E-mail: obarbasiewicz@gmail.com.

${ }^{2}$ The term popularized by Joseph S. Nye in his book Bound to lead: the changing nature of American power (1990), showing the appeal and attraction as a power shaping the preferences of others.
} 
and Korean music, called J-Pop and K-Pop. Germans and Poles read manga, discuss the latest anime, buy Korean cosmetics and eat sushi or kimchi for dinner. Japan and Korea, together with their unique culture and art, became part of the European lifestyle.

For East Asians, the Western European countries are for decades a symbol of elitism. The honeymoon tours, young Asians tours organized after graduation, are aimed to visit the Eiffel Tower, the Colosseum or Big Ben. Europe benefits from its long history without special care of Asian tourists when compared with the East Asian 'soft power'. Germans somehow use the image of the romantic churches and castles, cozy cafés, and European chic to attract part of the Korean and Japanese travelers. Poland attempts to promote its culture with Chopin and traditional crafts. Nonetheless, the must-see place for Asian tourists is still the symbol of the most tragic history of the nation: The Auschwitz-Birkenau concentration camp.

Besides the above-mentioned popular European sites for Asian nations, there is an issue in European history that raises interest among them. This issue is reconciliation.

History is both a factor in the process of remembrance and a dominant element in Polish-German relations. ${ }^{3}$ And reconciliation is a process that aims to soften the past burdens and enables the countries struggling in the past to establish a proper relationship. It can go back, freeze, or develop. One of the most important aspects of reconciliation is an apology.

The term apologia derives from Greek, and it is a term derived from oratory art, meaning defense speech against charges, as well as the praise of a person, piece of work or institution (SJP); in everyday speech, it can also mean justification or apologies. It is worth mentioning that the term combines conflicting slogans or an apology. It may be noted that the term apologia combines denial, justification, as well as an expression of repentance. For the purposes of this article, I focus on the apologies, defined as an agreement (Benoit, 2009, p. 92), or mea culpa (Tavuchis, 1991), which Jane W. Yamazaki calls the real apology (2006, p. 2).

This article aims at presenting and analyzing Polish and German paths for reconciliation. They are considered by Koreans as the one that should be repeated by Japan towards South Korea. ${ }^{4}$ Moreover, Japanese-Korean struggles over history will also be analyzed in this paper to show the failures

\footnotetext{
${ }^{3}$ See more in Feldman, 2012.

${ }^{4}$ See more in Barbasiewicz, 2019.
} 
that were committed by Asian nations. This analysis of the strengths and weaknesses of rapprochement attempts in both Europe and Asia aims at finding the solution and leads for the Western Balkans.

\section{POLISH-GERMAN PATHS FOR RECONCILIATION}

Poland and Germany share not only the memory of World War II atrocities. They also share 123 years of the occupation policy of Prussia towards large parts of Western Poland's territories, which ended in 1918. This period of occupation and the awareness of not existing Polish territory made the anti-German sentiment even stronger in the 1920s and the 1930s. The outbreak of World War II is the most clearly remembered in Polish history as a period of cruelty and dehumanization. The reconciliation process started about a decade after the war, and it is a constant course in Polish-German relations. However, it should be remembered, that the pre- and postwar situation of both countries was diametrically different. Poland became a part of the Soviet bloc, and Germany remained divided into the western and eastern parts. Therefore, the policy of dialogue was conducted from the Polish side with two different countries, and its own acceptance of Germany's gestures and statements was strongly controlled by the Soviet Union.

One of the most important aspects of the Polish-German dispute was the question of borders. Even though the agreement between the Polish government and East Germany (German Democratic Republic) was signed in 1950 (German-Polish society, 2012), the Polish western borders were still not recognized by West Germany (Federal Republic of Germany). East Germany did not also include regulations concerning the border traffic, which was of special interest to the Polish side. Nonetheless, the borders mentioned in the 1950 Treaty were agreed to be the official Polish-German borders. The relations with West Germany were established due to Ostpolitik, initiated in 1969 by the FRG Chancellor Willy Brandt as a normalization policy with the Central and Eastern European countries. Brandt's arrival to Warsaw in 1970 brought the Treaty of Warsaw, with acceptance of the existing borders. In the world's opinion, however, the most significant moment was the knee-fall of the German Chancellor in front of the Ghetto Heroes Monument. The picture of Willy Brandt kneeling in front of the monument, in the center of Warsaw, became the symbol of post-war apologies and is shown in numerous books and textbooks, not only in Europe but all over the world, including Asia. ${ }^{5}$ The

\footnotetext{
${ }^{5}$ However, it should be remembered that the pictures of Willy Brandt kneeling in front of the monument were prohibited in Poland until 1989. See more in Ruchniewicz, 2019, p. 23.
} 
final step to achieve the political status-quo regarding the borders' post-war uncertainty was the Treaty between the Federal Republic of Germany and the Republic of Poland on the confirmation of the frontier between them (Treaty between the Federal Republic of Germany and the Republic of Poland, 2002), signed in 1990. It was also supplemented by a Treaty of Good Neighbourship and Friendly Cooperation, signed in June 1991.

However, one of the most significant aspects of Polish-German reconciliation happened on the societal level. It was possible, after the Nuremberg Trials, which took place from November 1945 till October 1946. The trials recognized the guilt of the Nazis. Having this official confirmation of Germany's responsibility, the ground for rebuilding the relations was ready even the wounds were still opened.

In August 1948 the Hellmut von Gerlach Society was founded. It aimed to rebuild political, cultural and economic ties with Poland (Turek, 2018, p. 26). The first step to build the bridge of forgiveness was the cooperation of Christian churches (both protestant and catholic), which started in the 1950s, from the first cooperation of the protestant churches and neglecting antiPolish stereotypes in their publications (Żurek, 2019, p. 233). In 1964 and 1965, German Christians organized the pilgrimage to Auschwitz, which was the visible sign of the readiness for the process of reconciliation (Zurek, 2019, p. 234). The first key-event of Polish-German rapprochement was the Pastoral Letter of the Polish Bishops to their German Brothers, ended with a statement: 'We forgive and ask for forgiveness' (Text of the message, 2016). It seemed to be the most important document in the whole reconciliation process (Żurek, 2019, p. 237).

The symbolic culmination of the reconciliation process was the mass in Krzyżowa in Lower Silesia (Szurlej, 2013, p. 31), which took place on 9 November 1989. During this service, the symbolic gesture of the 'sign of peace' occurred between the Polish Prime Minister Tadeusz Mazowiecki and the West German Chancellor, Helmut Kohl.

Contemporarily, Poland and Germany share the commonwealth in a supranational organization, which is the European Union (EU). As Justyna Turek stated, mentioning the experience of Poland and Germany as a tool for compromise: 'European countries still grapple with obstacles concerning the reconciliation process, but Poland-German pattern seems to be a positive pattern (...). (...) steps of reconciliation based on forgiveness and mutual understanding - from political level and both societies - may have an excellent contribution to reconciliation (...). Forgiveness between adversaries is the first step in building relations and it is possible if we look 
at the European continent' (Turek, 2018, p. 21). This experience can become an instrument, which after adjusting to the cultural and historical understanding, can become a pattern for other countries on how to get through the most difficult path from two extreme points. As Burkhard Olschowsky and Robert Żurek claim, without German-French reconciliation, there would not be the European Union, but without PolishGerman reconciliation, there would not be the EU covering almost the entire continent (Olschowsky and Żurek, 2013, p. 40).

Poland and Germany were enemies during one of the bloodiest conflicts, World War II, due to which Poland lost almost 6 million citizens, i.e., 17\% of the pre-war population (Materski and Szarota, 2009). These days, they share common norms and values inside a supranational organism. It does not mean that past events do not overshadow the contemporary issues. They are visible in political propaganda, memorials and common anniversaries. But the path for understanding was opened. And since reconciliation, which is an ongoing process, aims at gaining a 'just memory', which is a proper resolution and forgiveness for others and oneself (Lavabre and Nicolaidis, 2009, pp. 87-88), the process between Poland and Germany can serve not as a perfect, but verified way to become co-partners, even if in not so distant past the nations could define each other as enemies.

\section{JAPANESE-KOREAN STRUGGLES OVER THE PAST}

The countries that definitely need the process of reconciliation are Japan and the Republic of Korea. Existing in a quasi-alliance, each of them is allied with the great-patron/protector - the United States. ${ }^{6}$ The establishment of the basic relations between these Asian democracies was caused by the pressure from the United States (Barbasiewicz, 2018). This 'push hard' policy of American policymakers towards rapprochement in the 1960s, caused the lack of the process of reconciliation and lasting struggles over history between both societies.

The outside pressure became the reason of history being an unworked issue in the bilateral relations of Japan and Korea. The source of the pressure was the special interest in sharing the responsibility of guaranteeing the security from the Japanese side to the Republic of Korea, during the increased American involvement in the Vietnam War. Together with forced

${ }^{6}$ This theory was developed by Victor D. Cha (2000). 
reconciliation, the incising sense of unfairness started to deepen in Japanese society. Japan, which was the aggressor during the war, due to its demilitarization, became one of the main suppliers of the American army fighting in Vietnam, while South Korea had to send the second largest contingent to support the US in the war. ${ }^{7}$ This situation caused the Korean human losses and the involvement in the next conflict, not that long after World War II and the Korean War. Japan, at the same time, benefiting from being the demilitarized country started its economic growth, leaving the rest of Asian countries far behind. ${ }^{8}$

The first attempts from the Japanese Emperor's side to express reconciliation started in the 1980s. On 6 September 1984, Japanese Emperor Hirohito held in his palace a party for South Korean President, Chun Doo Hwan. During the toast, he referred to the difficult past with words 'It is indeed regrettable, that there was an unfortunate past between us for a period in this century, and I believe that it should not be repeated again' (Haberman, 1990, p. 1). Soon after Hirohito passed away, Akihito, who succeeded, apologized to Korean President Roh Tae Woo while saying: 'I think of the sufferings your people underwent during this unfortunate period, which was brought about by my country, and cannot but feel the deepest regret' (Weisman, 1984, p. 5). This visit of the Korean president also became a possibility to draw attention to the "comfort women" issue. This was the beginning of how in the 1990s a new and ongoing historical struggle over the comfort women issue has started. Some scholars assume that about $70 \%$ of all comfort women were from Korea (Hicks, 1999, p. 113). The South Korean Women's and Church Women's Alliances and the Seoul District Female Students' Representative Council decided to ask President Roh to tackle the issue in Japan (Hicks, 1999, p. 113). The Korean president did not answer to this request, but the Korean Foreign Ministry requested the cooperation from the Japanese side in compiling a list of all wartime labor draftees (Hicks, 1999, p. 114). Soon after, the Socialists raised the issue in the Japanese Parliament. When the Japanese government denied, the anger among the ex-comfort women started to rise, and Kim Hak Sun decided for an official testimony. This led to the first lawsuits in Japan. When the Japanese government claimed that the documents concerning the issue were missing, Yoshimi Yoshiaki found the official papers in the Library of the National Institute for Defense Studies and delivered them as proof. The case

\footnotetext{
${ }^{7}$ See more in Kim, 1966.

${ }^{8}$ For detailed data, see Yoshioka and Kawasaki, 2016.
} 
of the comfort women became officially confirmed and a vivid issue in Japanese-Korean relations.

The change in the Japanese government and the period the Liberal Democratic Party lost the majority, led the Socialists to the PMs position. One of them was Murayama Tomiichi. He was the one, who made a statement on the occasion of the $50^{\text {th }}$ anniversary of World War II, considered by many as the closest to perfection. Murayama apologized: '(...) In the hope that no such mistake be made in the future, I regard, in a spirit of humility, these irrefutable facts of history, and express here once again my feelings of deep remorse and state my heartfelt apology. Allow me also to express my feelings of profound mourning for all victims, both at home and abroad, of that history (...)' (Statement by Prime Minister Tomiichi Murayama, 1995). Nonetheless, the usage of the issue of history in the political campaigns and the struggles over comfort women reparation caused not only political but also social hate.

The survey conducted among Japanese and Koreans from 2013 clearly shows that almost half of each society have bad impressions about each other. This does not help in building a common future and reconciliation. Besides the comfort women issue, the other 'burning points' are the territorial disputes (Takeshima/Dokdo Islands), and the lack of proper recognition from the Japanese government side (The Genron NPO and East Asia Institute, 2018).

The public opinion is formed by the actions undertaken by Japanese and Korean political and social actions that bring back to mind the past happenings. For example, before the first survey, in 2012 the Korean president visited disputed islands (Sang-Hun, 2012). The world was also informed of the willingness of the Korean side to construct an airport next to the islands (Nam, 2014). On the Japanese side, the actions of local politicians, as well as the statements made by the Prime Minister, also angered Koreans. For example, the statement by the mayor of Osaka, claiming that the comfort women were necessary for Japan's wartime soldiers ('Comfort women', 2013) brought much criticism not only in Korea but worldwide.

Even when Japanese Prime Minister Abe Shinzō and Korean President Park Geun Hye decided on the agreement on reparations for the sex slaves from Korea in 2015, it became the next issue of the struggle on history and apologies, which ended with a withdrawal of diplomats of both countries. The unwillingness on the Korean side could be caused by Abe's statement on the occasion of the $70^{\text {th }}$ anniversary of the end of World War II. He mentioned Korea among others who suffered from Japanese war actions, 
but with the emphasis that Japan 'repeatedly expressed the feelings of deep remorse and heartfelt apology for its actions during the war' and was 'consistently devoted to the peace and prosperity of the region since the end of the war' (Prime Minister of Japan and His Cabinet, 2015). This showed the entire world that Japan does not wish to apologize anymore, and the younger generations are not responsible for the war.

The above-mentioned, selected issues on Japanese history show how without the previous steps to the mutual forgiveness and understanding, every word in political speech, and every political or social action can become a great issue in bilateral relations. For sure, Japan and Korea are the countries that show the bad influence the lack of reconciliations has for the entire society.

\section{STRENGTHS AND WEAKNESSES OF POLISH-GERMAN RECONCILIATION AS A LESSON FOR THE BALKANS}

The above-mentioned process of Polish-German rapprochement and Japanese-Korean struggles over history do not mention the sole success of the first ones and the failures of the second pair of the countries. Poland and Germany still are the place of the historical disputes, but they established the benefits of coexisting as partners in different organizations, from which the most important and integrating are the EU and the North Atlantic Treaty Organization (NATO). It does not mean that Japan and South Korea do not participate in common organizations or do not share the security policy. But compared to Poland and Germany, they share only a common security patron - the United States, without being equal partners within bigger organizations, and - as it was shown above - without being equal partners within the triangular alliance (although the strongest feelings towards this state were during the Cold War period).

One of the strongest points of Polish-German cooperation is on the societal level. Different NGOs and organizations participate in establishing the Polish-German dialogue. One of the most important factors in building an understanding between the parties is the youth exchange program. A great example is the Polish-German Youth Cooperation. As it states in the mission: 'equality and partnership are the foundations of our activity. We work in a Polish-German team, we speak both languages, we are present in both countries'. ${ }^{9}$ These words are the best explanation of the success

\footnotetext{
${ }^{9}$ For detailed information visit the official website: https://www.pnwm.org/o-pnwm/ misja-i-wizja/.
} 
benefiting from building foundations for good neighborly relations between Poles and Germans. The Erasmus exchange program financed by the European Commission also helps Polish-German cooperation, making Germany one of the most frequently chosen countries for studying of Polish students, and German students as one of the most frequently studying at Polish universities (PL - one of the most popular Erasmus destination, 2014).

The next important step was establishing the Polish-German Textbook Commission, which is preparing one textbook on history, after agreeing on the universal version of the history of both Polish and German sides. Until today three textbooks were delivered to history teachers. The scope of topics in the published textbooks covers the period from prehistory until World War I and is defined as 'multi perspective' (Araszkiewicz, 2019, p. 15). The textbooks enforce the youths in understanding the past, which strengthens the willingness of students in searching and interpreting the sources, as well as looking for their credibility (Araszkiewicz, 2019, p. 15).

The weakest point in the attempts to reach full reconciliation and getting to a 'just memory' point is the lack of awareness on the German side of the atrocities committed on Polish citizens, with the parallel cultivation of this national tragedy in the Polish memory (Schmidt, 2019, p. 10). In Germany, Polish-German reconciliation is not appreciated, mostly because of the existing lack of interest in Eastern Europe and the biggest appreciation of German-French reconciliation (Olschowsky and Żurek, 2013, p. 40).

Consequently, the interesting result comes from the relations between Japan and South Korea. There is a significant interest in Korean pop culture, which causes a positive attitude of Japanese towards Korans (among all the negative attitudes presented in the previous chapter). ${ }^{10}$ It shows that besides the significant interest in the other country, reconciliation does not happen.

However, the actions aiming for the commemoration of the Polish victims in Berlin bring the hope of changing the lack of understanding on the German side. As one of the co-initiators, Leo Mausbach claims 'A Polish tourist who visits the sites commemorating World War II in the center of Berlin, will find in the Tiergarten district a monument in honor of Soviet soldiers, a monument in honor of the murdered Sinti and Roma, a memorial to homosexuals persecuted by Nazism and Holocaust memorial. He will also find places commemorating the German resistance movement and

${ }^{10}$ Around $50 \%$ of Japanese have a positive attitude towards Korea thanks to music, drama, or culture (The Genron NPO and East Asia Institute, 2019, p. 6). 
German suffering (...). Poland, in which there were the most victims of war in relation to the population, does not have its appropriate place here [in Berlin] to commemorate these victims and honor Polish resistance' (Mausbach, 2019, p. 11). It is very important since numerous scholars mention that the biggest obstacle to full reconciliation is the lack of awareness of the Polish nation that Germans call for honoring the Polish victims and the role of the Polish underground in World War II. However, on the political level, the remembrance of the atrocities committed against Poland is well remembered. For example, in the Bundestag, Angela Merkel recalled on the $75^{\text {th }}$ anniversary of the attack on Poland the responsibility of Germany in starting the war (Merkel reminds, 2014).

However, the researchers mention also the Polish politicians' approaches to destroy rapprochement while using the anti-German sentiment in their statements. The renowned Polish historian, Krzysztof Ruchniewicz (2019) mentions the changes that appeared in Polish society - blaming the Polish side for the worsening in relations between Poland and Germany. He referred to the public opinion survey conducted in 2017, in which according to Polish citizens the relations with Germany have worsened. ${ }^{11}$ Ruchniewicz also analyses the interview with Jarosław Kaczyński, the leader of the rightist-populist Law and Justice Party, who stated that Polish-German cooperation after the Cold War was the forced one and Polish elites were compliant towards Germany (Jarosław Kaczyński, 2017). ${ }^{12}$

The earlier breaking point in the bilateral relations was the activity of Erika Steinbach, and her activity in establishing the Centre Against Expulsions Foundation, which became the political issue before the elections in the Bundestag in 2005 (Turek, 2018, p. 39). Together with the Prussian Trust, an organization of German expellees established in 2000 made claims on the real estate left in Poland (Turek, 2019, p. 37). Poland perceived these activities as anti-Polish and depicting Germans as victims (Ziemer, 2005, p. 58). The German Chancellor Gerhard Schröder clearly stated that the attempts to claim in the courts were not supported by the German government (Ziemer, 2005, pp. 49-50).

The above-mentioned strengths (mainly depicted here as the contemporary societal activities, assuming that the political rapprochement is done) and weaknesses, caused by the activity of certain politicians, can

\footnotetext{
${ }^{11}$ Details could be seen in Roguska, 2017.

${ }^{12}$ The analyses conducted by Krzysztof could be seen in Ruchniewicz, 2019, pp. 15-27.
} 
become a clue for the Western Balkans seeking reconciliation. The activity of the politicians (even very important as Kaczyński in contemporary Poland, the leader of the majority party Law and Justice), cannot reverse elaborated reconciliation, but can significantly spoil it for a period of time. The solid ground is crucial, and the social exchange that raises the awareness of the other side can keep the fruits of reconciliation in a more difficult environment.

\section{CONCLUSIONS}

The aim of this article was to answer the question is there a universal pattern for reconciliation? In this paper, I attempted to present as case studies two different histories of post-war bilateral relations - in Europe and Asia. The case countries seem to be similar when taking into consideration the history of their relations, the trauma that was left in the societies after the war atrocities, and their contemporary role in the international society. Nonetheless, despite the similarities, the rapprochement process in Europe and Asia worked diametrically differently.

For sure, there is no universal pattern for reconciliation. Reconciliation is a never-ending process with its successes and failures. For sure, the role of the societal and religious organizations in the case of Poland and Germany used the opportunity of making first and very important steps to start this difficult and hard process of approaching to each other. These steps were taken when the burdens were still fresh. In the case of Korea, soon after gaining back independence after more than thirty years, the next tragic event took place, which left more scars on the societal structure - the Korean War. The interest of the big patron, the United States, and its occupational policy towards Japan, which enabled the country to stand beside all the military conflicts benefiting economically from the cooperation with the US, created the feeling of unfairness and the hard start from the beginning to establish the bilateral dialogue. The religion, which was the helpful spark for reconciliation in Europe, was not the case in Asia, where together with the occupational policy, the Japanese traditional religion - Shintoism (state version) was implemented.

The ongoing process of reconciliation in the case of West Germany was the outcome of Ostpolitik realized from the end of the 1960s. The Polish-East German relations were built on both countries' communist system and the need for the cooperation of the countries staying in the Soviet bloc. The end of the Cold War, and the active participation in the process of reconciliation of the societal and religious circles, helped to add to the official policy the 
aspect of rapprochement in which both sides played an active role - in this case it was the mass in Krzyżowa. This work of memory enabled future cooperation on the multidimensional level. The active role in introducing Poland to the organizations in which it became an equal partner for sure helped the societies to cooperate. The programs of the cooperation between the citizens of both courtiers, enforced by the opportunities given by the European Union (such as student exchange, legal work) or the free citizens' flow, strengthened the aspects of cooperation between the society and politicians.

In the case of Asian countries, history became a tool in the political campaign and is used to build the spirit of the nation. Even though there is the existence of a significant interest in other side's culture, the reconciliation process that was forced from the beginning effectively prevents agreement.

Therefore, even though the universal pattern for reconciliation does not exist, some aspects were characterized in this paper as helpful and disturbing in the process. Among them we can define:

- The victim's side should also be active in the process, not leaving reconciliation only to the former aggressor's side.

- Societal cooperation, such as exchange programs helps build rapprochement.

- The usage of history as a tool in gaining political power, when there is no strong reconciliation movements' history, disables and even pushes back possible rapprochement.

- Reconciliation should come from the need of the country (even if only one) or the certain benefit it wants to achieve in the international environment, not from outside pressure.

The Western Balkans, the region in Europe which was torn apart by wars after the fall of Yugoslavia, can for sure benefit from the interest of the European Union and the help of this organization in building peace and reconciliation in the region, together with the incorporation of all the states into this supranational organization. For sure, for the Balkans, it is easier to learn from the Polish-German experience because of the European roots of these countries. The Balkans have the path trodden by the central European countries - the EU member states. But it is also beneficial to look at the mistakes committed by the Asian countries. The EU cannot force the Western Balkans countries to reconcile. They need to find the benefit coming from the process of reconciliation and try to perceive how it helped Poland and Germany. 


\section{REFERENCES}

Araszkiewicz, W. (2019). Schatzkammer Schulbuch [Treasury school book]. Info. Magazin des Deutsch-Polnischen Jugendwerks, 2 (2019), pp. 14-15.

Barbasiewicz, O. (2018). Pushing hard from backstage: American influence onto the Japanese-Korean settlement and the contemporary triangular alliance in the Asia-Pacific region. Studia Polityczne, 46 (3), pp. 113-128.

Barbasiewicz, O. (2019). Annäherung als Vorbild für die japanischkoreanischen Beziehungen [Rapprochement as a model for JapaneseKorean relations], in: T. Skonieczny (Ed.), (Un)versöhnt? Gedanken über die deutsch-polnischen Beziehungen nach 1945 [(Un)reconciled? Thoughts about German-Polish relations after 1945] (pp. 123-140). Wrocław, Stiftung Kreisau für Europäische Verständigung.

Benoit, W.L. (2009). Sears' repair of its auto service image: Image restoration discourse in the corporate sector. Communication Studies, 46(1-2), pp. 89-105.

Cha, V.D. (2000). Abandonment, Entrapment, and Neoclassical Realism in Asia: The United States, Japan and Korea. International Studies Quarterly, 44 (2), pp. 261-291.

'Comfort women' snub Japan Osaka Mayor Hashimoto. (2013, May 24), retrieved from https://www.bbc.com/news/world-asia-22650673. Accessed 20 February 2020.

Feldman, L.G. (2012). Germany's Foreign Policy of Reconciliation. From Enmity to Amity. Lanham, Rowman and Littlefield Publishers.

German-Polish society. (2012). Gorlitz Treaty, retrieved from https:/ / web. archive.org/web/20120301135748/http://www.dpg-bundesverband. de/links_und_dokumente/bv_zeitgeschichte/1494147.html. Accessed 3 February 2020.

Haberman, C. (1990, May 25). Hirohito soothes Korean President. The New York Times, Section A, p. 1.

Hicks, G. (1999). The Comfort Women Redress Movement, in: R. Brooks (Ed.), When Sorry Isn't Enough: The Controversy Over Apologies and Reparations for Human Injustice (pp. 113-125). New York, NYU Press.

Jarosław Kaczyński o relacjach z Niemcami: „Nie możemy dalej się na to nabierać" [Jarosław Kaczyński on relations with Germany: "We cannot fool ourselves further"]. (2017, March 26), retrieved from https:/ / www. salon24.pl/newsroom/764206,jaroslaw-kaczynski-o-relacjach-zniemcami-nie-mozemy-dalej-sie-na-to-nabierac. Accessed 3 March 2020. 
Kim, J.A. (1966). Korean Participation in the Vietnam War. World Affairs, 129 (1), pp. 28-35.

Lavabre, M.C. \& Nicolaidis, D. (2009). Can we act on memory... in Mediterranean? The case of Algeria, in: D. Bechev \& K. Nicolaidis (Eds.), Mediterranean Frontiers: Borders, Conflict and Memory in a Transnational World. London \& New York, I.B. Tauries.

Materski, W. \& Szarota, T. (Ed.). (2009). Polska 1939-1945. Straty osobowe $i$ ofiary represji pod dwiema okupacjami [Poland 1939-1945. Victims of repression under two occupations]. Warsaw, Institute of National Remembrance.

Mausbach, L. (2019). Würdig erinnern - Wissen fördern [Remember worthily - promote knowledge]. Info. Magazin des Deutsch-Polnishen Jugendwerks, 2 (2019), p. 11.

Merkel reminds: It was Germany that started this war. We will never forget that. (2014, September 1), retrieved from http:/ / wiadomosci.dziennik. $\mathrm{pl}$ /swiat/artykuly/468520, angela-merkel-nie-zapominamy-oodpowiedzialnosci-za-wojne.html. Accessed 3 March 2020.

Nam, I.S. (2014, April 10). South Korea Plans Airport Near Disputed Islets, retrieved from https://blogs.wsj.com/korearealtime/2014/04/10/ south-korea-plans-to-build-airport-near-disputed-islets/. Accessed 30 March 2020.

Nye, J.S. (1990). Bound to lead: the changing nature of American power. New York, Basic Books.

Olschowsky, B. \& Żurek, R. (2013). Krzyżowa jako miejsce pamięci o polskoniemieckim dialogu społeczeństw przed 1989 r. oraz o mszy pojednania w 1989 r. [Krzyżowa as a place of remembrance about the Polish-German dialogue of societies before 1989 and about the mass of reconciliation in 1989], in: W. Czchur \& A. Franke (Eds.), Krzyżowa jako miejsce dialogu polsko-niemieckiego. Szanse na europejska narracje [Krzyżowa as a place for Polish-German dialogue. Chances for European narrative] (pp. 39-45). Krzyżowa, Fundacja "Krzyżowa" dla Porozumienia Europejskiego.

PL - one of the most popular Erasmus destination. (2014, August 25), retrieved from http://en.uw.edu.pl/pl-one-of-the-most-popularerasmus-destination/. Accessed 20 February 2020.

Prime Minister of Japan and His Cabinet. (2015, August 14). Statement by Prime Minister Shinzo Abe, retrieved from http://japan.kantei. go.jp/97_abe/statement/201508/0814statement.html. Accessed 20 February 2020. 
Roguska, B. (2017). Postrzeganie relacji polsko-niemieckich [Perception of Polish-German relations], retrieved from https://cbos.pl/SPISKOM. POL/2017/K_156_17.PDF. Accessed 3 March 2020.

Ruchniewicz, K. (2019). Die deutsch-polnischen Versöhnung: eine Bilanz nach 30 Jahren [German-Polish reconciliation: a record after 30 years], in: T. Skonieczny (Ed.), (Un)versöhnt? Gedanken über die deutsch-polnischen Beziehungen nach 1945 [(Un)reconciled? Thoughts about German-Polish relations after 1945] (pp. 15-27). Wrocław, Stiftung Kreisau für Europäische Verständigung.

Sang-Hun, C. (2012, August 8). South Korean's Visit to Disputed Islets Angers Japan, retrieved from https:/ / www.nytimes.com/2012/08/11/ world/asia/south-koreans-visit-to-disputed-islets-angers-japan.html. Accessed 30 March 2020.

Schmidt, A. (2019). Zukunft braucht Erinnetung [The future needs to be remembered]. Info. Magazin des Deutsch-Polnishen Jugendwerks, 2 (2019), p. 10.

SJP (Słownik Języka Polskiego). Apologia, retrieved from https://sjp.pl/ apologia. Accessed 19 November 2018.

Statement by Prime Minister Tomiichi Murayama "On the occasion of the 50th anniversary of the war's end". (1995, August 15), retrieved from https://www.mofa.go.jp/announce/press/pm/murayama/9508.html. Accessed 20 February 2020.

Szurlej, M. (2013). Jak doszło do mszy pojednania w Krzyżowej? [How did the reconciliation mass take place in Krzyżowa?], in: W. Czachur \& A.Franke (Eds.), Krzyżowa jako miejsce dialogu polsko-niemieckiego. Szanse na europejska narracje [Krzyżowa as a place for Polish-German dialogue. Chances for European narrative] (pp. 26-31). Krzyżowa, Fundacja "Krzyżowa" dla Porozumienia Europejskiego.

Tavuchis, N. (1991). Mea Culpa: A Sociology of Apology and Reconciliation Stanford, Stanford University Press.

Text of the message of Polish bishops to German from 1965. (2016, July 7), retrieved from https://dzieje.pl/aktualnosci/tekst-oredzia-biskupowpolskich-do-niemieckich-z-1965-r. Accessed 20 February 2020.

The Genron NPO and East Asia Institute. (2018, June 18). The 6th JapanKorea Public Opinion Survey Japan-Korea Public Opinion Comparison Results, retrieved from http:/ / www.genron-npo.net/world/archives/ 6941.html. Accessed 20 February 2020. 
The Genron NPO and East Asia Institute. (2019, June). The 7th Japan-South Korea Joint Public Opinion Poll (2019): Analysis Report on Comparative Data, retrieved from http://www.genron-npo.net/en/7th-JapanSouth\%20KoreaJointOpinionPoll.pdf. Accessed 3 March 2020.

Treaty between the Federal Republic of Germany and the Republic of Poland on the confirmation of the frontier between them. (2002, March 14), retrieved from https://www.un.org/Depts/los/LEGISLATION ANDTREATIES/PDFFILES/TREATIES/DEU-POL1990CF.PDF. Accessed 3 February 2020.

Turek, J. (2018). Europeanisation of Reconciliation: Polish-German Lesson for Asian States?, in: O. Barbasiewicz (Ed.), Postwar Reconciliation in Central Europe and East Asia. The case of Polish-German and Korean-Japanese Relations (pp. 19-52). Berlin, Peter Lang.

Weisman, S.R. (1984, September 7). Japanese express Remorse to Korea. The New York Times, Section A, p. 5.

Yamazaki, J.W. (2006). Japanese Apologies for World War II. New York, Routledge.

Yoshioka, S. \& Kawasaki, H. (2016). Japan's High-Growth Postwar Period: The Role of Economic Plans. Tokyo, Economic and Social Research Institute.

Ziemer, K. (2005). Polska i Niemcy - jaka przeszłość, jaka przyszłość? [Poland and Germany - what past, what future?]. Sprawy Międzynarodowe, 1, pp. 48-65.

Żurek, R. (2019). Wir gewähren Vergebung und bitten um Vergebung [We grant forgiveness and ask for forgiveness], in: T. Skonieczny (Ed.), (Un)versöhnt? Gedanken über die deutsch-polnischen Beziehungen nach 1945 [(Un)reconciled? Thoughts about German-Polish relations after 1945] (pp. 229246). Wrocław, Stiftung Kreisau für Europäische Verständigung. 